Ana Dili Eğitimi Dergisi
Journal of Mother Tongue Education
ADED - JOMTE
www.anadiliegitimi.com

\title{
Türkçenin Yabancı Dil Olarak Öğretiminde Materyal Geliştirme ve Materyallerin Etkin Kullanımı
}

Gül Banu Duman*

\begin{abstract}
Özet
Ders materyallerinin hazırlanması, ayrı bir uzmanlık ister. Öte yandan her öğretmen, materyal hazırlama ilkelerinden haberdar olmalı, gerektiğinde bu ilkeler doğrultusunda kendi materyallerini hazırlayabilmelidir. Materyal seçimi ve materyallerin yerinde kullanımı, başarıyı doğrudan etkiler. Bu sebeple materyal seçimi ve ne zaman hangi materyalden yararlanılacağı hususlarına da dikkat etmek gerekir.

Bu çalışmada materyal geliştirme ilkelerinin neler olduğu açıklanmaya çalışılmış, bu ilkeler, Türkçenin yabancı dil olarak öğretimi açısından değerlendirilmiştir. Daha sonra materyallerin eğitim öğretim sürecindeki ve Türkçenin yabancı dil olarak öğretimindeki yeri ve önemi üzerinde durulmuştur.
\end{abstract}

Anahtar Kelimeler: Materyal Seçimi, Yabancı dil olarak Türkçe öğretimi, Türkçe öğretiminde materyaller

\section{Material Development and Effective Use of Materials in Teaching Turkish as a Foreign Language}

\begin{abstract}
It's necessary to have proficiency in preparing course material. Besides, every teacher has to be aware of the principles of preparing course materials and if its required, has to be capable of preparing his/her own material by means of those. Choosing and using material directly affects success. Thus, Its needed to be careful about choosing material, which material used or when it practiced on.

In this survey, its searched what are the principles of advancing materials and those are questioned in terms of teaching Turkish as a foreign language. Then, its noticed that importance of the materials in process of education and teaching Turkish as foreign language. Its tried to introduce leading materials that will be used in teaching Turkish as a foreign language.
\end{abstract}

Key Words: Choosing material, teaching Turkish as foreign language, materials in teaching Turkish

* Yrd. Doç. Dr.; Bülent Ecevit Üniversitesi, Fen-Edebiyat Fakültesi, Türk Dili ve Edebiyatı Bölümü. E-posta: gulbanuduman@gmail.com 


\section{Giriş}

Yirminci yüzyılda hızla gelişen öğretim teknikleri, yirmi birinci yüzyılda da büyük bir ivmeyle gelişimini sürdürmektedir. Materyal geliştirme, öğretim tekniklerine paralel olarak her geçen gün gelişmiş, öğretim ve öğrenim sürecinin ayrılmaz bir parçası hâlini almıştır. Dolayısıyla günümüzde öğretim materyalleri geliştirme, başı başına bir uzmanlık dalı olmuştur. Materyaller, yabancı dil öğretiminde ve yabancı dil olarak Türkçenin öğretiminde, öğretimi-öğrenimi destekleyici bir unsur olarak öne çıkmaktadır.

\section{Materyal Geliştirme İlkeleri ve Türkçenin Yabancı Dil Olarak Öğretiminde Bu İlkelerin Yeri}

Öğretim materyallerinin hazırlanmasından uygulanmasına kadar her aşamada dikkat edilmesi gereken birçok husus vardır. Her materyal, öğretim sürecinin her döneminde kullanılamayacağı gibi her hedef kitle için uygun olmayabilir. Materyal kullanmak için materyal kullanmak, doğru bir yaklaşım değildir. Kullanılacak materyallerin, amaçlanan davranışları kazandırmaya yardımcı olması gerekir. İster yabancı dil, ister başka bir alan öğretimi için olsun materyal hazırlama ilkeleri ortaktır. Bu ilkeler birçok kaynakta şu şekilde sıralanmaktadır: "Anlamlılık ilkesi, bilinenden başlama ilkesi, çok örnek ilkesi, görelik ilkesi, seçicilik ilkesi, tamamlama ilkesi, fonun anlamlılı̆ı ilkesi, kapalılık ilkesi, birleştiricilik ilkesi, algıda değişmezlik ilkesi, derinlik ilkesi, yenilik ilkesi, basitlik ilkesi, hedef-davranış ilkesi, öğrenciye uygunluk ilkesi" (Demirel, Altun vd., 2011: 59-61; Yaylacı, H.S.ve Yaylacı F., 2013)

Yukarıda sıralanmış olan materyal hazırlama ilkeleri, yabancılara Türkçe öğretimi için hazırlanacak olan materyallerde de bulunması gereken genel ilkelerdir. Buna göre hazırlanacak materyaller, anlamlıık ilkesinde belirtildiği üzere anlamlı olmalıdır. Öğrenilen şeyler hedef kitle için bir anlam ifade ediyorsa akılda kalıcı olur. Yabancı dil olarak Türkçe öğretilirken yalancı eşdeğerlere de dikkat edilmesi gerekir. Aynı sesleri taşıyan kelimeler hedef dilde başka bir anlam, ana dilde başka bir anlam taşıyabileceğinden, hedef dildeki anlamın öğrenci zihninde uyandırılması ayrı bir öneme sahiptir.

Bilinenden başlama ilkesine göre, bilinenlerden başlamak, onların üzerine yeni bilgiler inşa etmek gerekir. Özellikle temel Türkçe seviyesinde, hedef kitlenin ana dilinde ve Türkçede ortak olan kelimelerin öğretimiyle başlanması, hem öğrenci grubuna güven aşılayacak hem de belli bir sözcük hazinesi oluşana kadar anlaşmayı kolaylaştıracaktır. Yabancılara Türkçe öğretmek için hazırlanmış materyaller, daha önce öğrenilen konuları da içeren, tekrar imkânı veren materyaller olmalıdır. Birçok konunun birbiri ile bağlantısı vardır. Hazırlanan ders materyalleri, bilinenlerden hareketle hazırlanıp eski bilgileri de içermeli öte yandan yeni bilgiler kazandırmayı hedeflemelidir.

Çok örnek ilkesi, diğer alanların öğretiminde olduğu gibi yabancılara Türkçe öğretiminde de geçerli bir ilkedir. Hazırlanan materyaller konuyla ilgili hedef kitleye bol örnek imkânı sunmalı, değişik alıştırmalar ile konunun pekiştirilmesini sağlamalıdır. Bunu gerçekleştirirken teknolojiden faydalanılması, bilgisayarlar ve akıllı tahtalar yardımıyla önceden hazırlanmış örneklerin sınıfta sunulması, zamandan tasarruf sağlamanın yanında, örneklerin çeşitli olmasına hizmet eder. Örnek miktarına, öğrenci grubunun algılama ve öğrenme hızına göre öğretmen karar vermelidir. Çok örneğin öğrenmeyi pekiştireceği bilinmekle birlikte, anlaşılan konularla ilgili gereğinden çok örnek verilmesi, hedef kitle için sıkıcı da olabilmektedir. Bu sebeple hangi konularda örneklerin arttırılacağı, hangilerinde örneklerin yeterli olduğu tamamen öğretmenin öğrenme grubunu dikkatli gözlemlemesiyle karar verilecek bir konudur. Örneklendirmede dersin süresine ve müfredata uygun hareket edilmelidir.

Görelik ilkesine göre, hazırlanan ders materyallerindeki resim ve şekiller, herkesçe aynı algılanacak şekilde net ve kolay anlaşılır olmalıdır. Herkes şekilleri birbirinden ayırt edebilmelidir.

Yabancılara Türkçe öğretimi için hazırlanmış materyallerin seçicilik ilkesine uygunluğu ise derste asıl öğretilmek istenen unsurun, en dikkat çekici şekilde materyale yerleştirilmesidir. Dikkat çekilmek istenen unsur bir dil bilgisi kuralı olabileceği gibi, kalıp bir ifade ya da bir kavram olabilir. 
Gerek yazılı materyal, gerek görsel ya da işitsel bir materyal olsun, dikkat çekilmek istenen unsurun, daha seçilebilir olarak materyale yerleştirilmesi gerekir.

Tamamlama ilkesine göre hedef kitle öğretilen konular arasında kendisi bağlantı kurabilmeli ve yeri geldiğinde eksiklikleri tamamlayabilmelidir. Konunun bütününden hareketle eksik parçaları tamamlama yetisi öğrenciye kazandırımalıdır. Boşluk doldurma tarzı alıştırmalar öğrencinin bütüne dikkat ederek, genelden hareketle boşluğu tamamlamasına yönelik çalışmalardır. Yarım bırakılan bir hikâyenin tamamlanması, verilen materyalden hareketle sonuç çıkarılması gibi etkinlikler de yabancılara Türkçe öğretiminde faydalı uygulamalardır.

Fonun Anlamlılığı ilkesi, öğretim materyalleri hazırlanırken verilmek istenen mesajın, görsel ya da işitsel fonla verilmesi anlamlılı̆ı arttıır, şeklinde tanımlanabilir. Yabancılara Türkçe öğretimi açısından düşünülecek olursa dilin malzemesi kelimelerdir. Kelime öğretiminde, hedef kitleye kelimenin anlamını verip geçmek yeterli olmaz. Ancak bir fon olarak düşünülebilecek bir cümle içinde kelimenin değişik anlamlarda ve durumlarda kullanımı örneklendirilebilirse öğretilmek istenen kelime daha anlamlı bir hâle gelir ve kalıcı olur. Anlatılanların görsel ya da işitsel (bir melodi, bir şarkı, küçük bir slayt... vb.) bir fonla desteklenmesi, etkiyi arttıran bir unsurdur.

Kapalıık ilkesi, daha çok görsel materyallerin kullanımında öne çıkan bir ilkedir. Bu ilke, görsel materyal olarak hazırlanmış şekillerin belirgin olması gerektiğini, açık ve yarım bırakıımamasını anlatmaktadır.

Birleştiricilik ilkesine göre, anlatılan konuların birbirleriyle olan bağlantıları ne kadar iyi verilirse; nesne, olay ve durumlar arasındaki ilişki ne kadar iyi kurulursa, dil öğretimi ile hedef kitlenin konuyu algılaması o denli birleştirici ve bütünleştirici olacaktır. Nesne, olaylar ve durum arasında bu türden bir bütünlük kurulması öğrenilenlerin daha kalıcı olmasını sağlar. Bu sebeple yabancılara Türkçe öğretimi için hazırlanacak materyaller, olaylar, nesneler hatta gramer özellikleri arasında bağlantı kurmaya yönelik hazırlanmalıdır. Birbiriyle bağlantılı gramer konuları ile ilgili karma alıştırmalar hazırlanması, bu gramerleri birbirleriyle karşılaştırabilme, hangi durumda hangisini tercih etmek gerektiği hususunda hedef kitleye yardımcı olacak, konunun bütün olarak kavranmasını sağlayacaktır.

Algıda değişmezlik ilkesine göre hedef kitle önceden bildiği kavramları, daha sonraki algılamalarında kavramın birçok özelliklerini aynı şekilde sürdürerek algılar. Türkçe öğretiminde de öğrenciler, daha önce öğrendikleri bir kavramı basit çizimlerle veya basit tariflerle kolaylıkla hatırlayacaklardır. Zaman zaman eski konulara göndermeler yapılıp, küçük çağrışımlarla o konuların unutulmasını önleyici türden materyallerden faydalanılmalıdır.

Derinlik ilkesi, görsel materyallerin hazırlanmasında dikkat edilmesi gereken bir ilkedir. Hazırlanan görsel malzemenin perspektife dikkat edilerek hazırlanmasını ifade eder. Bu ilkeye göre "Doğadaki varlıklar bize yakın ise gerçek ölçüleri ve renkleriyle görünürler. Aynı varlıklar uzaklaştıkça, insana küçülüyor ve renkleri de soluyor hissini verir." (Demirel, Altun vd., 2011: 60) Yabancılara Türkçe öğretimi için hazırlanan görsel malzemeler, bu tabiat kuralı göz önünde bulundurularak, gerçekçi bir şekilde hazırlandığı takdirde daha kolay algılanacaktır.

Yenilik ilkesine göre, her materyal eski öğrenilenleri pekiştirici olmasının yanında karşısındaki hedef kitlenin yaşantısına ya da bilgi düzeyine yeni bir şeyler eklemelidir. Dolayısıyla yabancılara Türkçe öğretmek için hazırlanmış her materyal de, eski bilgiler üzerine adım adım yeni tecrübeler, yeni bir kelime, yeni bir kavram, yeni bir bilgi inşa etmelidir.

Hazırlanan materyaller çok karmaşık, anlaşılmaz olursa dikkati üzerinde uzun süre toplayamaz. Bu sebeple hazırlanan materyaller, Basitlik ilkesi çerçevesinde basit ve anlaşılır olmalıdır. Özellikle temel Türkçede anlaşılır somut ifadeler seçilmeli, soyut düşünceler somutlaştırılarak verilmeye çalışılmalıdır.

Hedef-davranış ilkesi, yabancılara Türkçe öğretiminde dinleme-anlama, okuma-anlama, konuşma, yazma becerilerinden hangisi geliştirilmek isteniyorsa hedeflenen beceriyi geliştirmeye 
yönelik materyaller kullanılmasını içerir. En iyisi dört becerinin de dengeli bir şekilde kazandırımasıdır. Hedef kitlenin durumu dikkate alınarak, eksik olan beceriye yönelik materyaller kullanılmalı, dört beceri de ihmal edilmemelidir.

Başta da belirtildiği üzere her materyal her hedef kitle için uygun olmayabilir. Öğrenciye Uygunluk illkesi doğrultusunda, seçilecek materyallerin hedef kitlenin yaşına, ilgi alanlarına, zekâsına, bilgi düzeyine, geçmiş yaşantısına, öğrenme stiline... vb. uygun olması gerekir. Örneğin bozkır kültüründen gelen biri deniz ile ilgili kavramlara yabancı kalacaktır.

\section{Materyallerin Öğrenim - Öğretim Sürecindeki Yeri}

Öğretim-öğrenim sürecinde materyal kullanımı, şüphesiz ki öğrenimi destekleyici, hızlandırııı, öğrenilenlerin kalıcılığını sağlayıcı, öğrenme-öğretme sürecini daha ilgi çekici hâle getiren önemli bir unsurdur. Bu sebeple materyallerin öğrenim-öğretim sürecindeki yeri ve bu denli etkili olmasının sebepleri üzerinde durmakta da fayda vardır.

Halil ibrahim Yalın, araç-gereçlerin öğretimdeki yeri ve öneminden bahsederken araçgereçlerin neden gerekli olduğunu şu maddeler ışığında açıklar:

1. Çoklu öğrenme ortamı sağlarlar.

2. Öğrencilerin bireysel ihtiyaçlarının karşılanmasına yardımcı olurlar.

3. Dikkat çekerler.

4. Hatırlamayı kolaylaştırırlar.

5. Soyut şeyleri somutlaştırırlar.

6. Zamandan tasarruf sağlarlar.

7. Güvenli gözlem yapma imkânı sunarlar.

8. Farklı zamanlarda birbirleriyle tutarlı içeriğin sunulmasını imkân verirler.

9. Tekrar tekrar kullanılabilirler.

10. İ̧̧eriği basitleştirerek anlaşılmayı kolaylaştıırlar. (Yalın, 2010: 82-90)

Materyal kullanımı, daha çok duyunun öğrenme sürecine dâhil olmasına fırsat vermekte, bu da çoklu öğrenmeyi sağlamaktadır. Daha çok duyunun öğrenme sürecine dâhil olması, öğrenmeyi çabuklaştırdığı gibi, öğrenilenlerin kalıcı hale gelmesine yardımcıdır. Öğrencilerin farklı öğrenme stilleri olduğunu belirten Yalın (2010: 82), kimi öğrencilerin okuyarak, kimilerinin görerek, kimilerinin dinleyerek daha iyi öğrendiğine dikkat çeker. Değişik türde araç gereçlerin kullanımı ve araç sayısının artması bu farklı öğrenme stillerine sahip öğrencilere, ihtiyaçlarına uygun öğrenme fırsatı sunar. Farklı materyaller hedef kitlenin hangi yollarla öğrendiğini de keşfetmemizi sağlar.

Materyallerin dikkat çekici olması öğrenmeyi olumlu etkileyen bir diğer unsurdur. Materyaller sayesinde uzun belleğe görsel ve işitsel olarak kaydedilen bilgiler daha kalıcı olur ve bunların hatırlanma ihtimalleri artar. Türkçe öğrenen bir yabancıya, duyduğu her şey, başlangıçta çok uzak ve anlamsız gelecektir. Örneğin bir nesneyi uzun uzadıya tasvir ederek mi anlatmak daha kolaydır, yoksa bir görsel materyalden faydalanarak anlatmak mı? Bu anlamda materyaller, soyut kavramları somut ve anlaşılır kavramlara dönüştürmek açısından önemlidir. "Bir resim, bin kelimeye bedeldir." diyen Yalın (2010: 89) materyallerin zaman tasarrufu sağladığını anlatmaya çalışır. Sınıfa getirilmesi mümkün olmayan ya da tehlikeli olan cisim, olgu ve olaylar, özellikle görsel materyaller sayesinde çok kolay gözlemlenir hâle gelir. Görsel ve işitsel gereçlerin etkili kullanımı, anlatılması planlanan konuların öğretmenin hafızasından uçmasının önüne geçer. Yabancılara Türkçe öğretimi sırasında, özellikle temel Türkçede, meyveler, sebzeler, hayvanlar, meslekler gibi değişik konularda kelime yüklemesi yapılmasında fayda vardır. Önceden hazırlanan örneğin çok basit bir fotoğraf kataloğu sayesinde hem kavramlar kolay kavranır hem de bazı bilgilerin atlanmasının önüne geçilir. "Aa! Hayvanları anlatırken keçiyi atlamışım." gibi durumlar ortadan kalkar, her sınıfta tutarlı bir anlatım sağlanır. Bir kez hazırlanan bir materyali, değişik sınıflarda tekrar tekrar kullanmak da mümkündür. Kısacası materyaller, içeriği daha basit ve anlaşıır hâle getirmesi, zamandan tasarruf sağlaması bakımlarından öğretimde çok faydalıdır. Yabancılara Türkçenin öğretiminde de materyaller, etkili bir öğrenme sürecinin olmazsa olmazı durumundadır. 
Bilginin hatırlanma yüzdelerini bilmek, yabancılara Türkçe öğretiminde ders materyallerinin önemine bir kez daha dikkat çekecektir. "Bilginin hatırlanmasında okuma \%10, işitme \%20, görme \%30, görme ve işitme \%50, söyleme \%70, yapma ve söyleme \%90 etkilidir."( Demirel vd., 2011: 69; Yalın, 2010: 81)

Bu yüzdelerden de anlaşılıyor ki öğrenme sürecine ne kadar çok duyu dâhil olursa öğrenme daha etkili olmakta; öğrencinin konuşma becerisini geliştiren, pratiğe yönelik uygulamalar öğrenilenlerin kalıcı izli olmasını sağlamaktadır. Ayrıca bu yüzdeler, görsel ve işitsel materyallerin öğrenmede ne denli etkili olduğunu ortaya koymaktadır.

\section{Türkçenin Yabancı Dil Olarak Öğretiminde Materyallerin Yeri ve Önemi}

Her alan öğretiminde olduğu gibi yabancılara Türkçe öğretiminde de etkili materyal kullanımı önemlidir. Türkçenin öğretiminde kullanılan ve geliştirilen materyaller, hedef kitlenin daha çok duyu ile öğrenme sürecine katılmasını sağlayıcı nitelikte olmalıdır.

Seçilen materyaller amaca uygunluk yanında, dersin içeriği ile örtüşmelidir. Hangi temel becerinin öğretimi amaçlanıyorsa bu doğrultuda materyal seçimine gidilmelidir. Örneğin okuduğunu anlama becerisinde yazılı materyaller öne çıkarken, dinleme becerisinde ise işitsel materyaller önem kazanmaktadır. Bu sebeple kazandırılmak istenen temel becerilere göre materyal seçimi de doğal olarak değişir.

Yabancılara Türkçe öğretiminde kullanılan materyallerin niteliğini belirleyen önemli faktörlerden bir diğeri ise hedef kitlenin Türkçe bilme seviyesidir. Yani temel Türkçe, orta Türkçe ve yüksek Türkçe seviyesinde kullanılan materyallerin türü ve içeriği farklılık gösterir. Örneğin temel Türkçenin başlangıç seviyesinde sözcük öğretimi sırasında fotoğraflar, resimler gibi görsel materyaller çok gerekli ve etkilidir. Temel Türkçenin özellikle başlangıcında, öğretmen, hiç Türkçe bilmeyen ya da çok az bilen bir grupla karşı karşıyadır. Böyle bir hedef kitleye de sözcükleri Türkçe açıklamalarla anlatmaya çalışmak, etkisiz bir yöntem olacaktır. Önceden hazırlanmış görsel materyaller ile sözcüklerin yanlış anlaşılmasının önüne geçileceği gibi aynı zamanda sözcüğün öğretimi çabuklaşacak, zaman kazanılacaktır.

Yabancılara Türkçe öğretiminde, öğrenilenlerin tekrar edilmesi önemlidir. "Kısa süreli belleğe kaydedilen bilgi, üzerinde herhangi bir işlem yapılmadığı takdirde, 15-20 saniye içinde kaybolur. Fakat birtakım stratejiler ve tekrar yoluyla bilginin kısa süreli bellekte daha uzun süre kalması ve uzun süreli belleğe aktarılması sağlanabilir." (Yalın, 2010: 86) isşte bu noktada materyallere büyük görev düşer. Yabancılara Türkçe öğretmek için hazırlanmış ders ve çalışma kitaplarındaki alıştırmalar tekrar yapmak için ulaşılabilecek en kolay ders materyalidir. Materyal sayısı ve çeşidi arttıkça tekrar artacak, öğrenme kalıcı hâle gelecektir. Türkçe öğrenen bir yabancı, öğretmenin sınıfta verdiği bir kelimeyi, yazılı bir materyalde tekrar okursa, dinlediği bir şarkıda tekrar duyarsa, hatta o sözcüğü cümlede kullanırsa unutması daha zor olacaktır. Illetişimsel yöntemde belirtildiği gibi, öğrenci öğrenme sürecine ne kadar dâhil olursa öğrenme o ölçüde başarıya ulaşır. Yabancılara Türkçe öğretmek için hazırlanan ders materyalleri de öğrenciyi pasiflikten çıkarıp aktif hâle geçirici özellikte olmalıdır.

Yabancılara Türkçe öğretiminde kullanılacak materyallerde dikkat edilmesi gereken özellikler şu şekilde sıralanabilir:

1. Hedef kitlenin hazır bulunuşluluk düzeyi tespit edilmiş olmalı, aynı Türkçe seviyesine sahip kişilerin aynı kurlarda yer almasına dikkat edilmelidir. Hatta farklı dil ailelerinden olan öğrenciler mümkün olduğunca farklı sınıflarda olmalıdır. Türkçenin farklı lehçelerinin konuşulduğu ülkelerden gelen öğrencilerle, Afrika ya da Avrupa ülkelerinden gelen öğrencilerin aynı sınıfta olması sorun yaratacaktır. Türk cumhuriyetlerinden gelen öğrenciler, kendi dillerinin bir başka lehçesi olan Türkçeyi kolay öğrenirken, farklı dil ailesinden gelen öğrenciler kendi dillerinden bambaşka bir dil öğrendikleri için Türkçeyi daha zor öğreneceklerdir. Doğal olarak da dil ailelerine dikkat edilmeden yapılan bir sınıf homojen olmadığından, başarı sağlanamayacaktır. Türkçe ders materyalleri hazırlanırken de soydaş Türkler için farklı, yabancılar için farklı materyaller hazırlanmalıdır. Bu, yabancılara Türkçe öğreten 
herkes tarafından kabul edilmekle birlikte maalesef henüz soydaş Türkler için yeterince materyal yoktur. Kısacası soydaş Türklere mi, yabancılara mı Türkçe öğretildiği materyal hazırlanırken göz önünde tutulmalıdır.

2. Türkçenin yabancı dil olarak öğretilmesinde dikkat edilmesi gereken bir diğer husus ise materyallerin kolaydan zora, basitten karmaşığa, somuttan soyuta doğru bir sıra takip etmesidir. Bu ilke, materyal hazırlamanın da temel ilkelerindendir.

3. Yabancı dil öğretiminde bilindiği üzere dört temel beceri kazandırmak esastır: konuşma, yazma, okuduğunu ve dinlediğini anlama becerisi. Yabancılara Türkçe öğretimi için hazırlanan materyaller, bu dört beceriyi de geliştirmeye yönelik olmalıdır. Okunan ya da dinlenen bir materyalle ilgili sorular sorularak cevabın sözlü istenmesine göre konuşma veya cevabın yazılı istenmesine göre yazma becerisi geliştirilebilir.

4. Yabancılara Türkçe öğretimi için hazırlanan materyaller, öğretmen merkezli bir eğitim ortamı hazırlamak yerine, iletişimsel metoda göre hazırlanmış olmalı ve öğrenme sürecinde öğrenciyi aktifleştirmelidir. Yaparak yaşayarak öğrenme, öğrenmelerin en kalıcı olanıdır. Türkçenin yabancı dil olarak öğretiminde pratik yapmanın önemi inkâr edilemez. Yabancılara Türkçe öğretimi için hazırlanmış materyaller, öğrencileri derse katılmaya zorlayıcı olmalıdır. Yabancı dil öğreniminde pratik yapmak zorunludur. İngilizce öğretimiyle ilgili hazırlanmış $C D^{\prime}$ lerde, konuşma becerisini bile ölçen yazılımlar vardır. Doğru telaffuz edilmediğinde uyarı veren bu türden gelişsmiş materyaller, Türkçe için de hazırlanmalıdır.

"Etkili bir öğretimin temelinde, öğrencilerin dikkatlerini çekmek ve bunu öğretim süresince sürdürebilmek yatar... Hiç kimse öğrenme isteği duymadan öğrenemez." (Yalın, 2010, s.53) O hâlde yabancılara Türkçe öğretimi için hazırlanan materyaller, öğrencilerin derse daha aktif katılmalarına olanak sağlamalı, dikkati her daim canlı tutmalı, dersi tek düzelikten ve öğretmen merkezli olmaktan kurtarmalı, dersi eğlenceli, zevkli hâle getirmelidir.

5. Materyaller öğrencilerin bilgi düzeylerine uygun hazırlanmalıdır. Hem yazııı materyallerde, hem görsel-işitsel materyallerde gerek konular, gerek kelime, gerekse gramer düzeyi aşamalı olarak zorlaşmalıdır. Her bir materyalde birden fazla kalıp yerine tek bir kalıp verilmeli, önceki bilginin öğrenildiğinden emin olunduktan sonra yeni bilgilere geçilmelidir. Sınıfın öğrenme hızı öğretmen tarafından çok dikkatle gözlenmeli, öğrenme düzeylerini değerlendirmeye yönelik materyaller hazırlanmalıdır. Değerlendirme sonuçlarına göre eksik kalan bilgi ya da beceriyi geliştirmeye yönelik yeni materyaller uygulanmalıdır. Örneğin sınıfın okuma anlama becerisi iyi düzeydeyken dinleme anlama becerisi geri görünüyorsa dinleme anlama becerisini geliştirmeye yönelik materyallere ağırlık verilmelidir. Kısacası ölçme ve değerlendirme, öğrenme sürecinde öğrenmenin sağlıklı bir şekilde sürdürülebilmesi için çok önemli ve gereklidir. Sağlıklı bir ölçme değerlendirme başarılı bir öğrenme sürecini beraberinde getirir. Bu sebeple Türkçe öğrenen yabancılar için ölçme değerlendirmeye sık sık başvurulması gerekir. Ölçme ve değerlendirme, Türkçe öğretmeye geçmeden önce öğrencilerin hazır bulunuşluk düzeylerini ölçüp seviye sınıfları oluşturmak için kurun başında yapılmalı; Türkçe öğretmeye geçildikten sonra süreç devam ederken sık sık ara ölçme değerlendirmeler yapılarak bunların sonuçlarına göre öğretme sürecine yön verilmelidir. Son olarak da ünitenin ya da kurun sonunda ölçme ve değerlendirme yapılmalıdır. Sağlıklı bir ölçme değerlendirmenin yapılabilmesi için de ölçülmek istenen bilgi ve beceriye yönelik materyaller geliştirilmelidir. Demek ki materyaller, sadece Türkçe öğretmek, bilgi aktarmak için değil, öğrenmişlik düzeyini ve temel becerilerin kazanım seviyesini ölçmek için de kullanılmalıdır.

6. Hedef kitlenin yaşı, ilgi alanları, dil öğrenmedeki amaçları da materyal seçimini ve içeriğini etkileyen hususlardır. Örneğin ders kitaplarındaki metinlerin konuları, kelime düzeyleri, resim sayısı, gramer kalıpları gibi hususlar hedef kitlenin yaşına bağlı olarak değişmektedir. Yaşı küçük bireylerden oluşan hedef kitlelere Türkçe öğretmek için hazırlanmış ders kitapları, daha anlaşılır ve somut konuları işlemeli, daha bol resimli olmalı, daha basit gramerleri içermelidir. Öte yandan lisans ya da yüksek lisans eğitimi için Türkiye'de bulunan öğrencilere yönelik ders materyallerinin içeriği daha 
farklı olmalıdır. Üniversite eğitimi almak için Türkçe öğrenenlere, eğitim alacakları alana yönelik materyaller hazırlanmasında fayda vardır. Bu öğrenciler dört temel becerinin dördünde de iyi olmak zorundadırlar. Türkçeyi Türkiye'de sadece yaşamak için öğrenen bir yabancıya ise yazma becerisi diğer becerilere göre daha az gerekli olacaktır. Bu kişiler, özellikle dinleme-anlama, konuşma becerilerine ihtiyaç duyacağından bu becerileri geliştirmeye yönelik materyallere ağırlık verilmelidir.

7. Yabancı dil öğretiminde, kültürler arası yaklaşım da materyallerin içeriğini belirleyen bir başka noktadır. "Dil öğrenmek, kültür öğrenmektir." görüşünden hareketle, yabancılara Türkçe öğretmek için hazırlanan ders materyalleri Türk kültürünü aktarıcı özellikler taşımalıdır. Öte yandan materyal hazırlarken, Demir ve Açık'ın "Kültür aktarımı yapıyoruz diye bağlama uygun olmayan ya da dili ve yapıyı ögrretmek yerine sadece kendi kültürünü dayatmaya yönelik bir yol takip edilmemelidir." (2011: 56) uyarısını da dikkate almak gerekir. Seçilen ve hazırlanan materyaller, kültürü tanıtıcı olabilir; ama kültürü tanıtalım derken zorla dayatma yapılmamalıdır. Materyaller, kültür bombardımanı hâline getirilmemeli, kültürel unsurlar materyalin içinde konuyla örtüşerek verilmeye çalışılmalıdır; ama Türkçe öğretimi için hazırlanmış ders materyallerinde Türk kültürüne mutlaka yer verilmelidir.

Dilin, kültürün bir parçası olmasının yanında kültür aktarıcısı da olduğunu belirten (Bölükbaş ve Keskin 2010: 221) birçok dil uzmanı Türkçenin yabancı dil olarak öğretimi için hazırlanan materyallerde de kültürler arası yaklaşımdan yararlanmak gerektiğini kabul eder.

"Yabancı dil öğrenmede amacımı, kültürel yeterlilikleri kazanarak o dili daha iyi anlar, konuşur hale gelebilmektir. Bunu yapabilmek için o dilin sözcüklerinin nerede, ne zaman, niçin, kim tarafından hangi ortamda kullanıldığının bilinmesi ve kavranması oldukça önemlidir." (Demir, Açık 2011: 55) Bu da kültür aktarımı ile mümkündür.

"Başta öğretim programları olmak üzere öğretim materyali olarak öğrencilere sunulan her türden ders kitabı ve araç gereci, bireye kültürler arası sevgi hoşgörü mesajları içermeli, onun kişisel benliğini geliştirmeye katkıda bulunarak millî düşünce dünyasını oluşturmalı, oradan da evrensel düşünce dünyasına doğru ufuklar açmalıdır." diyen Güzel (2010: 112), yabancılara Türkçe öğretimi için hazırlanmış ders materyallerinin kültürel ve kültürler arası mesajlar içermesi gerektiğine vurgu yapmaktadır.

Yabancılara Türkçe öğretmek için hazırlanmış ders kitaplarının Türkçe öğrenen yabancılara Türk kültürünü de öğretmesi planlanmalıdır. Türk kültürünü öğretmek adına asıl hedef olan dil öğretimi ikinci plana atılmamalı, kültürel ögeler ders kitabına anlamlı ve dozunda yerleştirilmelidir. Türk kültüründen uzak bir yabancılara Türkçe kitabı düşünülemez. Duman (2003: 152)Türk soylulara Türkiye Türkçesi öğretiminde kullanılacak metinlerin taşıması gereken özellikler için "Hedef kitlemize Türkiye Türkçesi öğretiminde kullanılacak metinler, millî bağları kuvvetlendirecek; Türk dünyasında birlik sağlanması fikrini uyandırıp canlandıracak nitelikler taşımalıdır." diyerek ders materyallerinin kültür aktarımı işlevinin önemine dikkat çekmektedir.

\section{Sonuç}

Yabancılara Türkçe öğretiminde ne kadar çok farklı duyuya hitap eden materyal kullanılırsa öğrenme, o ölçüde kalıcı izli olacak ve çoklu öğrenme fırsatı öğrenciye sunulmuş olacaktır. Yazılı, görsel, işitsel materyallerin kullanımı dersi daha dikkat çekici hâle getirecek, dersi monotonluktan kurtaracaktır. Bütün bunların yanında bir öğretmenin hangi materyali ne zaman kullanacağını bilmesi, materyal hazırlama ve kullanma konusunda teknik donanıma sahip olması gibi unsurlar materyallerin başarısını etkilemektedir. Bir dil tam anlamıyla öğrenilmek isteniyorsa okuduğunu ve dinlediğini anlama, konuşma ve yazma becerilerinin hiçbiri inmal edilmemeli, bu dört beceriyi de geliştirmeye yönelik materyaller kullanıımalıdır. Öğretmen tarafından sınıf gözlenmeli hangi beceri geriden geliyorsa o beceriyi geliştirmeye yönelik materyallerin kullanımına ağırlık verilmelidir. Bu arada bilgisayar, projeksiyon gibi teknolojik gelişmelere uygun ders materyalleri ile donatılmış sınıflar öğrencilerin daha bir hevesle Türkçe öğrenmelerine olanak sağlar. Unutulmaması gereken bir diğer 
nokta da yabancılara Türkçe öğreten her öğretmen, aktif bir şekilde bu materyalleri kullanabilmeli ve gerektiğinde kendi materyalini kendisi hazırlayacak kapasiteye sahip olmalıdır.

Türkçenin yabancı dil olarak öğretilmesi ve öğrenilmesinde de materyallerin önemi yadsınamaz; ancak unutmamak gerekir ki bir materyal ne kadar iyi hazırlanmıs olursa olsun o materyali uygulayacak olan öğretmen faktörü, çok daha önemlidir. "Öğretmen, öğrenme-öğretme sürecinin en önemli ögesidir. Öğretmen, öğrenme-öğretme sürecinde giriş etkinliklerini, içerik sunumunu, geri bildirimi, araç-gereç seçimini, yöntem seçimini ve değerlendirmeyi planlayan ve yöneten kişidir." (Demirel, Altun vd., 2011: 34) Dolayısıyla materyal seçiminden, materyal uygulama becerisine kadar öğretmenin her türlü tutumu öğretim sürecine yön verir; materyalin etkin kullanımına olanak sağlar. Öğretmenin materyal kullanma becerisinin yanında, sınıfı oluşturan bireylerin hazır bulunuşluluğu; sınıfın bilgi düzeyi, yaşı, ilgi alanları, dil öğrenme becerileri; süre; maddi imkânlar; hedef kitlenin Türkçeyi Türkiye'de yaşarken öğreniyor olup olmadığı gibi birçok husus da materyal seçimini etkileyen etkenlerdir.

Önemli bir diğer husus da materyalin süresinin önceden iyi hesaplanmasıdır. Sınıfta uygulanan materyalin yarım kalması, uygulamanın bir sonraki derse bırakılması öğrencinin aradaki bağı kuramamasına yol açabilir. Görsel, işitsel materyallerde materyalin uzunluğuna dikkat edilmeli, örneğin 20 dakika materyal dinlendiyse, 20 dakika da materyal hakkında hedef kitle konuşturulmalı, soru cevap yöntemiyle öğrencinin derse katılımı sağlanmalıdır.

Sonuç olarak, Türkçenin yabancı dil olarak öğretilmesine yönelik eğitim materyalleri, hedef kitlenin değişik duyularına hitap ederek onlara çoklu öğrenme imkânı sunmalı, öğrencilerin hazır bulunuşluluk düzeylerine uygun seçilmeli, bireysel farklılıkları dikkate almalı, öğrenciyi aktifleştirmeye yönelik, yaşayarak öğrenme ilkesine göre tasarlanmalı, dikkat çekiciliği yanında kolay kullanılabilir ve kolay anlaşılır olmalıdır.

\section{Kaynakça}

Arslan, M. ve Adem, E. (2010). Yabancılara Türkçe öğretiminde görsel ve işitsel araçların etkin kullanımı. Dil Dergisi. 147, 63,86.

Başkan, Ö. (2006. Yabancı dil öğretimi ilkeler çözümler. İstanbul: Multilingual Yayınları.

Bölükbaş, F. ve Keskin, F. (2010). Yabancı dil olarak Türkçe öğretiminde metinlerin kültür aktarımındaki işlevi. Turkish Studies. Volume 5/4 Fall, 221-235.

Demir, A. ve Açık, F. (2011). Türkçenin yabancı dil olarak öğretiminde kültürlerarası yaklaşım ve seçilecek metinlerde bulunması gereken özellikler. Türklük Bilimi Araştırmaları (TÜBAR). 30, 51-72.

Demirel, Ö. (1990). Yabancı dil ögrretimi, ilkeler, yöntemler, teknikler. Ankara: USEM Yayınları.

Demirel, Ö. (2011). Yabancı dil öğretimi, dil pasaportu, dil biyografisi, dil dosyası. Ankara: Pegem Yayınları.

Demirel, Ö. ; Altun, E.; Ateş, A.; Başboğaoğlu, U.; Çelik, L.; Çeliköz, N.; Erişen, Y.; Oral, B.;Taşlı, H.; Tekinarslan, E. ve Yağcı, E. (2011). Öğretim teknolojileri ve materyal tasarımı. Ankara: Pegem Yayınları.

Duman, A. (2003). Türk soylulara Türkiye Türkçesi öğretiminde metin seçimi. TÜBAR. XIII, 151-154.

Göçer, A. (2007). Türkçenin yabancı dil olarak öğretiminde kullanılan ders kitaplarının ölçme ve değerlendirme açısından incelenmesi. Dil Dergisi. 137, 30,46.

Güzel, A. (2010). iki dilli Türk çocuklarına Türkçe öğretimi. Ankara: Öncü Basımevi.

Seferoğlu, S. S.(2010). Öğretim teknolojileri ve materyal tasarımı. Ankara: Pegem Yayınları.

Yalın, H. I. (2010). Öğretim teknolojileri ve materyal gelişstirme. Ankara: Pegem Yayınları.

Yaylacı, H.S ve Yaylacı, F. (2013). Eğitim teknolojisi dersinde öğretim materyallerinin geliştirilmesi. http://www.egitim.aku.edu.tr/yaylaci.htm web sitesinden 04.03.2013 tarihinde alınmıştır. 